\title{
Suitability of some well water for different human uses by studying some physicochemical properties
}

${ }^{1}$ Department of Biology, College of Education for Pure Science, University of Tikrit, Iraq

${ }^{2}$ Ministry of Education, Salah Al-din Directorate, Iraq

Corresponding author: muqdadaltae@yahoo.com

Abstract: The present study is carried out to identify $(\mathrm{pH}, \mathrm{EC}, \mathrm{TDS}$, alkalinity, total hardness, calcium Ca, magnesium Mg, sulfate $\mathrm{SO}_{4}$, chloride $\mathrm{Cl}$, ) and $\mathrm{Mpn}$ cell / 100ml Total number of coliform bacteria of groundwater indicators in some wells within villages of Al-Dhuluiya, Al-Alam in Salahuddin and wells from Kayara (Al-Jawaana and Al-Jadaa villages). Four wells were studied for two seasons from November, December 2016 and January 2017. Results of this study showed that there was a seasonal variation in some chemical and physical factors. The groundwater was neutral because pH values were ranged (7-8.6). Electrical conductivity values were between (2543-50305) micro siemens. Total hardness values were within permissible limits (12002800 mg/L). Calcium and magnesium hardness between (1000-1950) mg /L, (100-1282) mg /L, respectively. Total dissolved solids were between (261-3245). Chloride ions (Cl-) in groundwater of studied samples were within the permissible limits for watering of animals and irrigation of plants, with values range $(79-259 \mathrm{mg} / \mathrm{l})$ and sulfate values were in range $(460-1055) \mathrm{mg} / \mathrm{L}$. The total number of coliform were between (3-240) cell/100 ml.

Key words: Groundwater, physicochemical parameters, wells, TDS, pollution.

\section{Introduction}

Groundwater can be defined as the portion of the water between two layers and the filtration of rainwater into the soil and lower ground layers. Thousands of years ago, groundwater was one of the most critical water supplies that humanity relied on, especially in dry and semi-arid regions where millions of people lived ${ }^{1}$. It is distinguished by a high concentration of dissolved salts when compared to river water. This could be due to the slow movement of groundwater, which dissolves sections of the rocks it passes through, and the salts changed into it. The majority of these salts are calcium and magnesium. This water's mineral content separates it from other bodies of surface water. The salt ingredients vary depending on the geological nature of the place ${ }^{2}$. Groundwater was employed for agricultural purposes in village settings when no other water resources were accessible. Human activities have progressively contaminated groundwater ${ }^{3}$. The quality of groundwater results from the interactions of many processes during the hydrological cycle. It is varied according to the depth, different places and nature of geological formation ${ }^{4}$.

Groundwater lacks suspended materials due to the infiltration process through which the water passes; therefore, deep well waters are colorless, pure, and have stable compositions, compared with less deep well waters. The depth of well waters and their isolated conditions make their temperature almost constant or change only a few degrees. This is important in the field of industry and thermodynamics ${ }^{5}$. Because of the low levels of the Tigris and Euphrates rivers and the recent rain drought, the demand for well water in Iraq has declined recently. Groundwater in Iraq is becoming increasingly significant for drinking and irrigation ${ }^{6}$. The primary goal of this study was to assess well water quality and suitability for diverse uses by investigating some physical and chemical aspects of good samples collected.

\section{Materials and methods}

\section{Description of the research field}

Four wells were selected within villages of Al-Dhuluiya, Al-Alam in Salahuddin government and wells from Kayara (Al-Jawaana and Al-Jadaa villages). The study areas have geological formation areas and sea level characteristics.

\section{Well 1}

This well is located at a depth of 10 meters in Al-Alam, a populous region. This well is now closed and is only utilized for home purposes and irrigation.

\section{Well 2}

It is located in Al-Dhuluiya at a depth of $20 \mathrm{~m}$, and it is of the open type and used for crops irrigation.

\section{Well 3}

It is located in the village of Al-Jawaana at a depth of 15 $\mathrm{m}$. The well is of the closed type, which is used for crops irrigation also.

\section{Well 4}

The well is located in Al-Jadaa village at a depth of $40 \mathrm{~m}$,

Citation: Salman Dalas I, Altae M, Mukdad Mahmood R. Suitability of some healthy water for different human uses by studying some physicochemical properties. Revis Bionatura 2022;7(1). 26. http://dx.doi.org/10.21931/RB/2022.07.01.26

Received: 2 December 2021 / Accepted: 21 January 2022 / Published: 15 February 2022

Publisher's Note: Bionatura stays neutral with regard to jurisdictional claims in published maps and institutional affiliations. 
and it is of closed type and used for irrigation.

\section{Sample Collection}

Water samples were collected from different wells from November, December 2016 and January 2017. Standard methods of sample collection and laboratory analysis were followed $^{7-9}$ by taking one sample per month during the study period. Physiochemical measurements were performed as follows: $\mathrm{pH}$, Electrical Conductivity and $\mathrm{pH}$ were measured by using (pH-EC meter, HI 9812, Hanna instrument), TDS, Total Alkalinity: The method of correction with sulfuric acid (N 0.01) was followed by the presence of the orange instance, Total hardness and Ca hardness was measured with standard N2EDTA $(N 01,0)$ with Erichrom Black T and Murexide as dry powder respectively 7,8, Calcium (Ca), Magnesium (Mg), Sulphate $\left(\mathrm{SO}_{4}\right)$, Chloride $\mathrm{Cl}$-: was measured by correction with standard silver nitrate solution ( $\mathrm{N} 0.0141$ ) with potassium dichromate ${ }^{8,9}$, and Mpn cell / 100ml (Total number of coliform bacteria).

\section{Statistical Analysis}

The computer was used through the ready-made statistical program, SPSS, (the load test of variance and the Duncan test, a test that shows us which of the categorical variables differs from the other in the occurrence of changes. The studied significance at the level of significance $p \leq 005$.

\section{Results}

\section{$\mathrm{pH}$}

Values of $\mathrm{pH}$ of the present study are shown in table (1) The maximum $\mathrm{pH}$ value was (8.6) found in the Al-Jwaana well in November and the minimum value was 7 in wells of Salahuddin government as in table (1). Analysis of variance showed significant differences in different times and the different wells $(\mathrm{P} \leq 00.05)$.

\section{Electrical conductivity EC}

The conductivity values in the different wells ranged from $2543 \mu \mathrm{hs} / \mathrm{cm}$ in January in Al-Alam well to $50305 \mu \mathrm{hs} / \mathrm{cm}$ in January in Al-Jadaa well. The statistical analysis showed significant differences $(P \leq 00.05)$ among the different wells. These values are shown in table (2).

\section{Chloride}

Differences were observed in the values of chloride table (3). The minimum and maximum ranges of the chloride value were (59-259)mg/L. The analysis of variance revealed considerable temporal differences $(P \leq 00.01)$. During the study period, there were no geographic disparities between the wells.

\section{Alkalinity}

The alkalinity ranges of the samples during the study pe- riod are shown in table (4). Values were from $80 \mathrm{mg} / \mathrm{L}$ to 160 $\mathrm{mg} / \mathrm{L}$. Results were statistically significant $(\mathrm{P} \leq 00.05)$ spatially and non - significant temporal.

\section{Total Hardness}

The total hardness values are shown in table(5). The total hardness during the study period ranged from $1200 \mathrm{mg} / \mathrm{L}$ in November in Al-Jadaa well to $2800 \mathrm{mg} / \mathrm{L}$ in both of November and January months in Al-Jwaana well. Statistical analysis revealed that there were significant regional differences $(P \leq 00.05)$ and significant temporal differences $(p \leq 00.01)$.

\section{Calcium and Magnesium hardness}

The maximum value of calcium hardness was $1950 \mathrm{mg} / \mathrm{L}$, and the minimum value was $1000 \mathrm{mg} / \mathrm{L}$, and magnesium hardness was (200-1282) mg/L among the different wells. Analysis of variance showed significant spatial difference $(P \leq 00.01)$. Table (6) shows these values. Table (7) shows the values of the magnesium hardness, which were (160- 2600) mg/L. Statistical analysis showed significant spatial and temporal differences $(p \leq 00.01)$.

\section{Sulfate $\left(\mathrm{SO}_{4}\right)$}

As shown in Table (8), the relative sulfate values for wells were (460-1055) mg/L. In January, a water sample taken at Al-Alam well found a low concentration of $460 \mathrm{mg} / \mathrm{L}$, while a water sample taken at Al-Dhuluiya revealed a maximum concentration of $1055 \mathrm{mg} / \mathrm{L}$.

\section{Total Dissolved Solids (TDS)}

Electrical conductivity (EC) and total dissolved solids (TDS): As indicated in Table (9), the TDS was obtained for four wells from different areas ranging from (261-3245) mg/L.

\section{Drinking water coliform bacteria}

In this study, as in Table (10), all wells were revealed bacteria pollution. Results were between (3-240). Maximum and only high value was in Al-Alam well in November.

\section{Discussion}

The $\mathrm{pH}$ of aquatic systems is an excellent indicator of water quality and contamination extent. The results of this study differed slightly from those of Ghaeeb's ${ }^{10}$ on the physical, chemical, and bacteriological properties of some wells in Tikrit city (7.49- 7.83).

\section{EC}

At $25{ }^{\circ} \mathrm{C}$, the ability of one $\mathrm{cm} 3$ of water to transmit electrical current is defined. This factor is assessed by $(\mu \mathrm{hs} / \mathrm{cm})$ or (Mhs/cm). Conductivity depends on the soluble salts concentration and water temperature ${ }^{11}$. All of the readings were close, but the Al-Alam well in January was 50305, which could

\begin{tabular}{|l|l|l|l|l|}
\hline Well Month & November & December & Jan & Mean of Wells \\
\hline Al-Dhuluiya & 7.1 & 7.4 & 7 & $7.16 \mathrm{~A}$ \\
\hline Al-Alam & 7 & 7.6 & 7.2 & $7.26 \mathrm{~A}$ \\
\hline Al-Jadaa & 7.6 & 7.5 & 7.8 & $7.63 \mathrm{~A}$ \\
\hline Al-Jawaana & 8.6 & 7.3 & 7.7 & $7.86 \mathrm{~A}$ \\
\hline Mean of months & $7.58 \mathrm{a}$ & $7.45 \mathrm{a}$ & $7.43 \mathrm{a}$ & \\
* Similar symbols indicate no significant differences
\end{tabular}

Table 1. pH values during the study period. 


\begin{tabular}{|l|l|l|l|l|}
\hline Well Month & November & December & Jan & Mean of Wells \\
\hline Al-Dhuluiya & 3503 & 4062 & 3767 & $3777.3 \mathrm{C}$ \\
\hline Al-Alam & 3745 & 2863 & 2543 & $3050.3 \mathrm{D}$ \\
\hline Al-Jadaa & 6651 & 6410 & 50305 & $21122.0 \mathrm{~A}$ \\
\hline Al-Jawaana & 4270 & 4431 & 6095 & $4932.0 \mathrm{~B}$ \\
\hline Mean of months & $4542.3 \mathrm{~b}$ & $4441.5 \mathrm{~b}$ & $15677.5 \mathrm{a}$ & \\
\hline
\end{tabular}

* Similar symbols indicate no significant differences

Table 2. Electrical Conductivity EC( $\mu \mathrm{hs} / \mathrm{cm})$ values during the study period.

\begin{tabular}{|l|l|l|l|l|}
\hline Well Month & November & December & Jan & Mean of Wells \\
\hline Al-Dhuluiya & 200 & 259 & 230 & $229.67 \mathrm{~A}$ \\
\hline Al-Alam & 192 & 150 & 167 & $169.67 \mathrm{~B}$ \\
\hline Al-Jadaa & 150 & 191 & 200 & $180.33 \mathrm{~B}$ \\
\hline Al-Jawaana & 79 & 99 & 81 & $86.33 \mathrm{C}$ \\
\hline Mean of months & $155.25 \mathrm{a}$ & $174.75 \mathrm{a}$ & $169.5 \mathrm{a}$ & \\
\hline
\end{tabular}

* Similar symbols indicate no significant differences

Table 3. Chloride $\mathrm{Cl}(\mathrm{mg} / \mathrm{L})$ values during the study period.

\begin{tabular}{|l|l|l|l|l|}
\hline Well Month & November & December & Jan & Mean of Wells \\
\hline Al-Dhuluiya & 120 & 140 & 160 & $140.0 \mathrm{~A}$ \\
\hline Al-Alam & 80 & 115 & 140 & $111.7 \mathrm{~B}$ \\
\hline Al-Jadaa & 120 & 100 & 80 & $100.0 \mathrm{~B}$ \\
\hline Al-Jawaana & 160 & 140 & 120 & $140.0 \mathrm{~A}$ \\
\hline $\begin{array}{l}\text { Mean of months } \\
\text { * Similar symbols indicate no significant differences }\end{array}$ & 123.8 a & 125.0 a & \\
\hline
\end{tabular}

Table 4. Alkalinity (mg/L) values during the study period.

\begin{tabular}{|l|l|l|l|l|}
\hline Well Month & November & December & Jan & Mean of Wells \\
\hline Al-Dhuluiya & 1800 & 2500 & 2200 & $2166.7 \mathrm{~B}$ \\
\hline Al-Alam & 1400 & 1950 & 1400 & $1583.3 \mathrm{C}$ \\
\hline Al-Jadaa & 1200 & 1200 & 1800 & $1400.0 \mathrm{D}$ \\
\hline Al-Jawaana & 2800 & 2500 & 2800 & $2700.0 \mathrm{~A}$ \\
\hline Mean of months & $1800.0 \mathrm{~b}$ & $2037.5 \mathrm{a}$ & $2050.0 \mathrm{a}$ & \\
\hline
\end{tabular}

* Similar symbols indicate no significant differences

Table 5. Total hardness ( $\mathrm{mg} / \mathrm{L})$ values during the study period.

\begin{tabular}{|l|l|l|l|l|}
\hline Well Month & November & December & Jan & Mean of Wells \\
\hline Al-Dhuluiya & 1000 & 1218 & 1200 & $1139.3 \mathrm{C}$ \\
\hline Al-Alam & 1200 & 1500 & 1000 & $1233.3 \mathrm{~B}$ \\
\hline Al-Jadaa & 1000 & 1100 & 1600 & $1233.3 \mathrm{~B}$ \\
\hline Al-Jawaana & 1600 & 1450 & 1950 & $1666.7 \mathrm{~A}$ \\
\hline Mean of months & $1200.0 \mathrm{c}$ & $1317.0 \mathrm{~b}$ & $1437.5 \mathrm{a}$ & \\
\hline
\end{tabular}

* Similar symbols indicate no significant differences

Table 6. Calcium Ca (mg/L) values during the study period.

\begin{tabular}{|l|l|l|l|l|}
\hline Well Month & November & December & Jan & Mean of Wells \\
\hline Al-Dhuluiya & 800 & 1282 & 1000 & $1027.3 \mathrm{~A}$ \\
\hline Al-Alam & 200 & 450 & 400 & $350.0 \mathrm{~B}$ \\
\hline Al-Jadaa & 200 & 100 & 200 & $166.7 \mathrm{C}$ \\
\hline Al-Jawaana & 1200 & 1050 & 850 & $1033.3 \mathrm{~A}$ \\
\hline Mean of months & $600.0 \mathrm{~b}$ & $720.5 \mathrm{a}$ & $612.5 \mathrm{~b}$ & \\
\hline
\end{tabular}

Table 7. Magnesium Mg(mg/L) values during study period. 


\begin{tabular}{|l|l|l|l|l|}
\hline Well Month & November & December & Jan & Mean of Wells \\
\hline Al-Dhuluiya & 1023 & 1055 & 933 & $1003.67 \mathrm{~A}$ \\
\hline Al-Alam & 460 & 468 & 502 & $476.67 \mathrm{C}$ \\
\hline Al-Jadaa & 835.2 & 625 & 816 & $758.73 \mathrm{~B}$ \\
\hline Al-Jawaana & 610.68 & 841.34 & 805 & $752.34 \mathrm{~B}$ \\
\hline Mean of months & $732.22 \mathrm{a}$ & $747.34 \mathrm{a}$ & $764.00 \mathrm{a}$ & \\
\hline
\end{tabular}

* Similar symbols indicate no significant differences

Table 8. $\mathrm{SO}_{4}$ (mg/L)values during the study period.

\begin{tabular}{|l|l|l|l|l|}
\hline Well Month & November & December & Jan & Mean of Wells \\
\hline Al-Dhuluiya & 261 & 275 & 446 & $327.33 \mathrm{D}$ \\
\hline Al-Alam & 1171 & 1112 & 1030 & $1104.33 \mathrm{C}$ \\
\hline Al-Jadaa & 2850 & 2563 & 3245 & $2886.00 \mathrm{~A}$ \\
\hline Al-Jawaana & 1013 & 1588 & 1232 & $1277.67 \mathrm{~B}$ \\
\hline Mean of months & $1323.75 \mathrm{c}$ & $1384.50 \mathrm{~b}$ & $1488.25 \mathrm{a}$ & \\
\hline
\end{tabular}

* Similar symbols indicate no significant differences

Table 9. (TDS) mg/L values during study period.

\begin{tabular}{|l|l|l|l|l|}
\hline Well Month & November & December & Jan & Mean of Wells \\
\hline Al-Dhuluiya & 3 & 9 & 21 & $11.0 \mathrm{C}$ \\
\hline Al-Alam & 240 & 21 & 43 & $101.3 \mathrm{~A}$ \\
\hline Al-Jadaa & 43 & 75 & 21 & $46.3 \mathrm{~B}$ \\
\hline Al-Jawaana & 64 & 9 & 9 & $27.3 \mathrm{C}$ \\
\hline Mean of months & $87.5 \mathrm{a}$ & $28.5 \mathrm{~b}$ & $23.5 \mathrm{~b}$ & \\
\hline
\end{tabular}

* Similar symbols indicate no significant differences

Table 10. Mpn Total account of bacteria (cell/100ml) values during the study period.

be related to rainfall, which washes away salts from nearby soils. The current work's results were comparable to 19207675) Al-(Obaidy's hs/cm in Salahuddin Province's northwestern region ${ }^{12}$.

\section{Alkalinity}

Most groundwater carbonate and bicarbonate ions are derived from carbon dioxide in the soil ${ }^{13}$. The alkalinity values ranged between $80 \mathrm{mg} / \mathrm{L}$ and $160 \mathrm{mg} / \mathrm{L}$. This could be due to the high rate of organic matter decomposition by bacteria and an increase in carbon dioxide (CO2), which will result in the creation of bicarbonate ${ }^{14}$.

\section{Total hardness}

Show the concentration of calcium and magnesium, which can precipitate when heated and have a detrimental impact on the solubility of soap in water ${ }^{15}$. Some wells have a high value, which could be attributed to rains washing away salts from adjacent soils.

\section{Calcium and Magnesium hardness}

Calcium and magnesium ions enter the groundwater through infiltration from minerals like Calcite, Gypsum and Dolomite ${ }^{14}$. Results of this study were similar to the study of Safawi and others (2008) in their study on well water of the Shrikhand-Kubba region in Nineveh province, where they record a range of $(720-1900) \mathrm{mg} / \mathrm{L}^{16}$.

\section{Sulphates}

Some bacteria, such as chlorothiobacteria and rhodo- thiobacteria, oxidize their ores and produce $\mathrm{H} 2 \mathrm{~S}$ due to their activity. Their ions are found naturally in water and have had little or no impact on human health so far. In this study, the maximum concentration of $1055 \mathrm{mg} / \mathrm{L}$ was obtained for water sample taken at location Al-Dhuluiya, which maybe because of the sewage from the village. All values were below the $\mathrm{WHO}^{17}$ $400,100,250$, and $200 \mathrm{mg} / \mathrm{L}$ are the maximum allowed limits, respectively. However, a buildup of sulfate in water can cause an increase in $\mathrm{pH}$, resulting in acidosis ${ }^{18}$.

\section{Total dissolved solids}

Only water samples located within Al-Dhuluiya revealed average TDS values within the permissible value $(500 \mathrm{mg} / \mathrm{L})$ of the world standards. Maximum TDS is a sign of saline water, which can be caused by natural solute dissolving and weathering, and by discharge from industrial treatment plants, which causes soil contamination leaching and point-source groundwater pollution ${ }^{19}$. Implications of high TDS are organoleptic in humans and reduction in pipes, filters, and valves due to scale accumulation ${ }^{20}$. The ionic concentration of a water sample, which influences its ability to conduct an electric current, is measured by EC, which is directly connected to TDS. The ionic strength of a water sample increases as the TDS content rises. The results were higher above the permitted limit of $1000 \mu \mathrm{S} /$ $\mathrm{cm}$ set by international drinking water guidelines. Ionic heavy metals were dissolved during industrial activities involving heavy machinery and later found their way into groundwater through leaching of sub-soil layers ${ }^{21}$, and greater temperature of the location boosting mobility of ions under electrostatic potential might be blamed for the unbearable EC value ${ }^{22}$. The 
main adverse effects are water corrosivity and heavy metals, which render the water unfit for consumption.

\section{Total coliforms}

Are a type of bacteria that can be found in the environment, such as soil or vegetation, as well as in humans. Although total coliform bacteria are unlikely to cause sickness, their presence signals that more dangerous microbes may contaminate your water source. Escherichia coli is the only member of the entire coliform bacterial genus that can only be found in the intestines of mammals, including humans. E. coli contamination of water implies recent fecal contamination and may indicate the presence of disease-causing microorganisms such as bacteria, viruses, and parasites. Because testing for all known pathogens is a complicated and expensive operation, total coliforms and E.coli are employed as indicators to determine the degree of contamination and hygienic quality of healthy water. The primary source of pathogens in drinking water is recent contamination from human or animal waste, improperly treated septic and sewage discharges, animal manure leaching, and stormwater runoff. Domesticated or wild animals Bacteria and other dangerous microbes from any source may be carried into rivers, lakes, or groundwater during and after precipitation. Poor good construction or poor maintenance can increase the risk of groundwater contamination. Bacterial contamination was discovered in all wells in this investigation. The highest and only high value was at Al-Alam in November. It could be the result of animal excrement leaching near wells, as well as poorly installed septic and sewage systems and household charges.

\section{Conclusions}

During the study period, the $\mathrm{pH}$ and EC levels in all wells were within the allowable range for drinking water. Also, the chloride concentration is below permissible levels, and all wells have been tested to ensure that they pose no threat when utilized for residential purposes. According to the general guidelines for hardness water categorization, most water in wells is standard.

\section{Funding}

This research was funded by self.

\section{Acknowledgments}

I would like to extend my thanks and gratitude to all who support us.

\section{Conflicts of Interest}

None

\section{Bibliographic references}

1. Mahdi M J . Study groundwater in Samarra and try to improve its quality in a manner chemical deposition and ion exchange. Master Degree / college Engineering-Tikrit University. 2008.

2. Mahjoub M R. Microbiology of water. Dar Al-Hikma Press Printing Press Baghdad University. 1998; 368 p.

3. Mishra A and Bhatt $\vee T$. Physico-Chemical and Microbiological Analysis Under Groundwater in V. V Nagar and Nearby Plales of Anand District Guiarat, India. E-Journal of Chemistry. 2008; 5(3):487-492 p.
4. Alexander P. Evaluation of groundwater quality of Mobi town in Admawa State, Nigeria . Africa Journal of Biotechnology . 2008; 7(11):1712-1715.

5. Al-Obeidi M A N . Environmental study on the quality of groundwater in the district of Al-Twz and its villages, Master Thesis, college of Science, University of Tikrit. 2014.

6. Jawad M A and Nassif D M. Study of the chemical and physical properties of some groundwater well sand the extent of their pollution In the city of Samarra. DIYALA JOURNAL FOR PURE SCIENCEs. 2013; 11 (4) : 15-23

7. Abawi S A \& Hassan S M. Practical Engineering for Environment Water Testing 7. Dar Al-Hikma Directorate for Printing and Publishing Mosul. University of Mosul. 1990.

8. ASTM . Annual Book of ASTM (Standards American Society for Testing and Materials). Philadelphia, USA. 1989; PP:11.

9. APHA. American Public Health. Association., Standard Methods for the Examination of Water and Wastewater .20th Edition. APHA. American Water Works Association. (AWWA), and Water Pollution Control Federation, Washington, DC 1998.

10.Ghaeeb M G F. Ecological Study of the Physical, Chemical and Bacteriological Characteristics to Some Wells in Tikrit City. thesis of Master College of Science, University of Tikrit. 2010.

11 . Hem J D. Study and interpretation of the chemical characteristics of natural water, Third Edition. USGS. United State Governorate Printing Office. 1985.

12. Al-Obaedy H H. Ecological study on the Quality of Groundwater North of Salahuddin province. Master of science, College of science, University of Tikrit. 2010.

13. Faure G . Principles and Application of Geochemistry 2nd prentice Hall Inc. , USA. 1998; 600p.

14.AL-Amar A B. The Quality of groundwater for selected area in south of Babylon governorate Iraq .(IOSR- JAGG). 2015; 2321(3):29-36

15. Bojan Antoni'c , Dani Dordevíc , Simona Jan cíková, Bohuslava Tremlova and Ivan Kushkevych. Physicochemical Characterization of Home-Made Soap from Waste-Used Frying Oils. Processes journal, 2020; 8, 1219.

16. Safawi, Abdel-Aziz Younes; Ali, Faeq Hassan; Kanna, Abdel Moneim Ali. Physical and chemical evaluation of some wells in the Sherikhan-Kubba area and their suitability for drinking and domestic use. Proceedings of the Sixth Periodic Scientific Conference of the Dams and Water Resources Research Center. 2008; 193-201 p.

17. WHO, World Health Organization. Guidelines for Drinking-water Quality, 1st Addendum to the 3rd ed., volume 1: Recommendations, World Health Organization, Geneva, 2006515p .

18. Asamoah AA, Amorin BS. Assessment of the quality of bottled sachet water in the Tarkwa-Nsuaem municipality in Ghana. Res $J$ Appl Sci. 2011; 3(5):105-113.

19. Boyd, C.E. Water Quality: An Introduction. Kluwer Academic Publishers Group, The Netherlands. 1999.

20. Atekwanaa EA, Atekwanaa EA, Roweb RS, Werkema DD, Legalld FD. The relationship of total dissolved solids measurements to bulk electrical conductivity in an aquifer contaminated with hydrocarbon. J Appl Geophys. 2004; 56(4):281-294.

21. Eruola AO, Adedokun NA. Analytical assessment of cadmium, lead and iron in hand dug wells of Ilaro, South Western Nigeria. Glob J Sci Front Res Chem. 2012; 12(6):23-29.

22. Oguntona TS, Adedeji OO, Martins OC. Contamination of Sachet water produced within industrial area of Ikeja, Lagos Nigeria. Int J Environ Sci. 2012; 3(2):23-29. 